\title{
Quality Assurance of Transformational Leadership in Education
}

\author{
Novi Nurhayati*, Asep Sudarsyah \\ Educational Administration Program \\ Universitas Pendidikan Indonesia \\ Bandung, Indonesia \\ *novinurhayati87@upi.edu
}

\begin{abstract}
This research is to describe and analyze the quality assurance of transformational leadership of Head of Teachers and Educators Development Division (P3TK) to the subordinates in an education organization at meso- (middle) dimension amid the occurring Covid-19. The method applied is that of qualitative-descriptive approach with research instruments of observation, interview and documentation. The research shows that quality assurance of transformation leadership is crucial to be implemented at meso-dimension of education world to improve service delivery by education staff to education personnel operating in the field so as to maximize harmonious personal interaction during Covid-19 pandemic that has been taking place for a relatively long time.
\end{abstract}

Keywords-education dimension, quality assurance, transformational leadership

\section{INTRODUCTION}

Law No. 200 of 2003 concerning National Education System underlined that education would be implemented in a single national education system to reach the objectives of national education, inter alia, to develop the competencies and to enhance the quality of life and human dignity of Indonesian people. The introduction of this law brings some implications, which include the need of a nationwide education quality standard. Out of various instruments, Government Regulation No. 19 concerning National Education Standard can be adopted as a national standard for education, which is applicable for a wide variety of types and hierarchies of education units [1].

Quality assurance in education world is a process, through which the civilization of Indonesian people will be determined with the implementation of education management capable of encouraging self-actualization values compatible with the goals of education to be pursued from the on-going "4.0 Digital" global life towards "5.0 Society" civilization [2]. Human resources constitute key factors for successful education management, and by maximizing the existing facilities as well as other improvements following the latest demands such human resources, coupled with quality assurance of education leadership, will be able produce human civilization [3]. In light of that, several quality control concepts relating to education leadership, which is fit to the demands of "5.0 Society" have been reviewed. Some discourses have been conducted to get picture of the real education conditions amid Covid-19 outbreak [4]. The components of transformational leadership consisted of: 1) Charisma, 2) Intellectual Stimulation, and 3) Individualized Attention, and of course their impacts to the followers, which all of them will be capable of enhancing the quality of education product and its process according to currently-needed standards and requirements [5].

Education dimension has become an interesting topic of discussion, since its implementation process constitutes a relatively long stage as a system or even a supra system, which is inter-correlated. Education process run by the Government of Indonesia is to enrich the life of nation that will turn Indonesia into a modern civilized nation. Based on the most important component of education, i.e. planning, education will be carried out through three main dimensions: (a) macro-level of Minister, (b) meso-level of District/City, and (c) micro-level of education unit. In this research, the dimension to be analyzed with regard to assurance quality of transformational leadership is that of education dimension at meso-level, i.e. District/City level especially the leadership of Division Head [6].

\section{A. Literature Review}

This research raises three parts of discussions, which are inter-correlated, i.e. education dimension, transformational leadership and quality assurance.

1) Education dimension: Education is more interpreted as an intentional attempt to assist in developing the personalities and competencies of students with guidance, teaching and or training activities [7]. Thus, in its implementation there is a main process stage, i.e. education planning [8]. In the field, this education planning has several dimensions, namely, macro-dimension, meso-dimension and micro-dimension. Basically educations dimensions are performed at macro, meso and micro scales when delivering education services to the students through a series of administered education processes. At macro-scale it is the responsibility of the 
Government in this case the Minister. For meso-scale, education is provided by regional government, i.e. District/City, and education at micro-scale is run by education units (Elementary, Junior Secondary, Senior Secondary and equivalents) [6].

2) Transformational leadership: Bass postulated a transformational leadership theory built from earlier ideas of Burns. The level of transformational leadership is particularly measured from the effect of such leadership to the followers [9]. The leaders accomplish this process of motivating and transforming followers by (1) heightening their awareness of the importance and value of designated goals, (2) encouraging them to transcend self-interest for the good of the organization or team, and (3) activating their higher order. The original formulation of this theory covered three components of transformational leadership, i.e.: 1) Charisma, 2) Intellectual Stimulation, and 3) Individualized Consideration. Burns who is admitted as the first founder of transformational leadership defined transformational leadership as "a process in which leaders and followers raise to higher levels of morality and motivation". This leadership style will be able to raise the motivation of followers to explore productive ideas, to forge synergic relation, responsibility, educational concern, and common aspirations [9].

3) Quality assurance: Quality Assurance is a Processbased approach with main objective of preventing defect product from planning stage to product delivery stage to the customers so as to avoid any rework and customers' complaints that can tarnish the reputation of company and incur extra-costs to fix poor quality products. Quality Assurance is a pro-active process focusing on planning, documentation and setting quality standards before a project starts to understand the requirements and the expected quality standards. Once all requirements and the expected quality standards have been identified, the next step is to develop the planning to comply with such requirements and quality standards. There are three techniques or tools that can be used to assure the quality of a product inclusive of Quality Audit, Process Analysis, Quality Management and Control Tools [10].

In Quality Audit, an expert team coming from external third party (not from internal of the company) will review the process and procedures established by the company. As to Process Analysis, it refers to analysis to every process to find out any potential defect product or process expected not having any added value, from which the contributing factors can be identified and the remedial actions can be formulated. Quality Management and Control Tools cover a variety of diagram techniques to assist in detecting problems, remedies, decision making and priority issues that must be dealt with first. Some examples of Quality Management and Control Tools are Tree Diagram, Affinity Diagram, Networking Diagram, etc [11].
4) Quality assurance to leadership value measurement: The scores of quality assurance produced from the instruments must be confirmed with validity to the acquired scores. Validity refers to single conception called Construct Validity [12-14]. Several aspects of construct validity are:

- Content - evidence of relevancy and representation;

- Substantive - how and why the object of measurement will respond and how such response will affect the questionnaires;

- Structural - internal structure of measurement, i.e. factorial validity;

- Generazability - How far the results of measurement correlate with other relevant measurements;

- External - evidence of criteria relevancy;

- Consequential - how far the measurement is fair and unbiased, both at item level or test level;

The above-mentioned six aspects are validity evidence. In light of that, validity for quality assurance of measurement results is a series of big process in the form of a mosaic of convergent and discriminant findings that support the scores of measurement results. The newer literatures offer comprehensive perspective of this validity as assurance to the quality of scores produced by the instrument [15].

The importance of finding validity evidence based on the following aspects: 1) Logical/Theoretical Analysis; 2) Latent Process Studies; 3) Practical Constraints; 4) Item Design Principles; 5) Domain Structure; 6) Test Specifications; 7) Psychometric Properties; 8) Scoring Models; 9) Utility; 10) Other Measures; and 11) Impact [16]. These 11 aspects not stand alone but inter-correlated, as illustrated in Figure 1. The scheme in Figure 1 depicts validity system. Straight lines denote direct impacts; broken lines mean feedback. The sources of internal and external evidence can be found in lower lines.

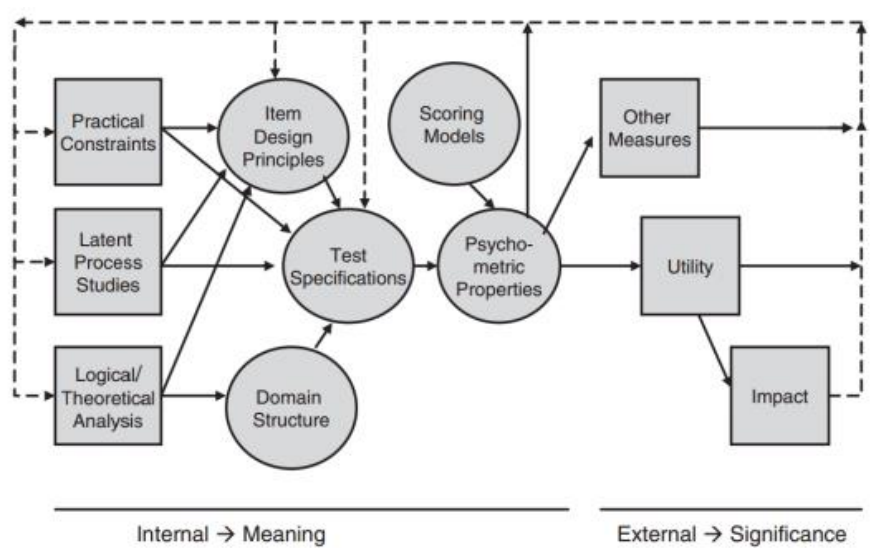

Fig. 1. Embretson's universal validity system (2007)

For example, to illustrate quality assurance process of measurement scores, below is presented validation process 
posited in transformational leadership measurement validation. A number of measurement items have been developed for response by persons in the surrounding of a leader to be measured, particularly the subordinates. These items are:

- Shows that he/she cares about me

- Acts as a person that I look up to

- Creates lessons that really encourage me to think

- Demonstrates that he/she believes in me

- Treats me in ways that build my respect

- Is enthusiastic about what I am capable of achieving

- Provides me with tasks and challenges that get me to think in different ways

- Motivates me to try my hardest

- Tries to know every student in the class

- Get me to question my own and others' ideas

- Tries to help students who might be struggling

- Talks about his/her personal values

- Encourages me to look at issues from different sides

- Recognized the needs and abilities of each student in the class

- Is optimistic about what I can accomplish

- Behaves as someone I can trust [17].

\section{B. Our Contribution}

This research is dedicated for the development of roles played by the leaders in assuring the quality of their followers to produce maximum performance, especially stakeholders, actors and implementers of education policies at meso organization dimension of City District/ District level, in this case Education Agency, in serving education personnel, i.e. operational staff in the field to assure successful education and learning process at education units being the spearheads of a series of education process, from which harmonious education system will be established. The outcomes of this research are particularly dedicated to education organization, i.e. Education Agency of Bandung Municipality, Teachers and Educators Development Division (P3TK), and education academicians in general.

\section{Paper Structure/ Research Method}

Method used in this research is that of quantitative descriptive analysis. The data is collected with observation techniques from Education Agency Office of Bandung Municipality and interviews using ordinal scale questionnaires and documentations obtained from staff of Education Agency of Bandung Municipality, Teachers and Educators Development Division (P3TK).
1) Respondents: All staff within Teachers \& Educators Development Division (P3TK) totaling 21 persons.

2) Instrument: Interview and observation questionnaires cover the following scopes:

- Validation of instruments to quality assurance of transformational leadership, 15 questionnaires

- Implementation of transformational leadership (amid Covid-19 pandemic), 10 questionnaires.

The assessment is scored with ordinal scales set in the following rankings:

- $\quad$ Highly Agree = 5

- $\quad$ Agree $=4$

- $\quad$ Doubtful $=3$

- $\quad$ Disagree $=2$

- $\quad$ Strongly Disagree $=1$

The assessment criteria are as follows:

- $4,01-5,00 \rightarrow \mathrm{SB} /$ Excellent

- $3,02-4,00 \rightarrow \mathrm{B} / \mathrm{Good}$

- $2,01-3,00 \rightarrow \mathrm{CB} /$ Fair

- $1,01-2,00 \rightarrow \mathrm{KB} /$ Poor

- $0,00-1,00 \rightarrow \mathrm{B} /$ Very Poor

\section{BACKGROUND RESULTS AND DISCUSSION}

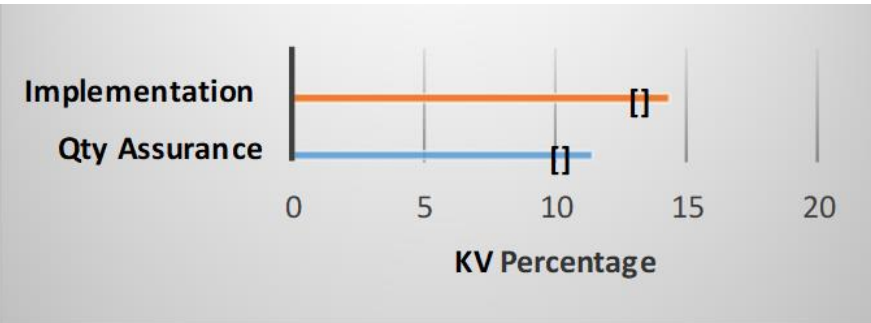

Fig. 2. The percentage of coefficient of variance to quality assurance and implementation of transformational leadership.

\section{A. Quality Assurance of Transformational Leadership}

According to data compiled from questionnaires that have been distributed to all staff within P3TK as the followers of Transformational Leadership it shows that the percentage of coefficient of variance is getting smaller, i.e. $14.4 \%$ and $11.4 \%$ as indicated in figure 2 above. From the same figure 2 it can be also found that quality assurance of transformational leadership of Head of P3TK Division during Covid-19 plague is good for the followers as evident from criteria calculation as follows:

$$
\text { Mean }=\frac{\Sigma f}{n}=\frac{877}{16}=54,8
$$


Criteria $=$

$\frac{M}{\text { item }}=\frac{548}{15}=$

3,65. then the assessment criteria is B (Good)

$$
\begin{gathered}
\text { Deviation Standard } S^{2}=\frac{\sum\left\lceil X_{i}-\overline{\mathrm{x}} \mathrm{j}^{2}\right.}{n-1}=\frac{593}{15}=38,86 \\
S=\sqrt{3} 8,86=6,23 \\
\mathrm{KV}=\frac{6283}{54,8} \times 100=11,4 \%
\end{gathered}
$$

The calculated data is taken from responses given by all followers from the distributed questionnaires that have been completed with the specified criteria and as such able to ascertain that quality assurance of transformational leadership by Head of P3TK Division has run in sound and effective manner, which despite the occurring Covid-19 has significant influence over the entire education policies at meso-level.

\section{B. The Implementation of Transformational Leadership}

The implementation of transformation leadership in all education activities at meso-level, i.e. staff attached to Teachers \& Educators Development Division (P3TK) has run well as obvious from responses given by the staff and the relatively small percentage of coefficient of variance at $14.4 \%$ as presented in figure 2 , and the following calculation:

$$
\begin{gathered}
\text { Mean }=\frac{\Sigma f}{n_{M}}=\frac{5 a 2}{16}=33,3 \\
\text { Criteria }=\frac{{ }_{M}}{\text { item }}=\frac{193}{10} 3,33 .
\end{gathered}
$$

the the assessment criteria is $B$ (Good)

$$
\begin{gathered}
\text { Deviation Standard } S^{2}=\frac{\sum\left(X_{\mathrm{i}}-\mathrm{x}\right)^{2}}{n-1}=\frac{343}{15}=22,86 \\
S=\sqrt{ } 22,86=4,78 \\
\mathrm{KV}=\frac{4,78}{33_{13} \mathrm{x}} \times 100=14,4 \%
\end{gathered}
$$

The assessment criteria for the implementation of transformational leadership by Head of P3TK Division as obtained from the calculation of respondents' responses is to range at 33.3, which means in good criteria under ordinal scales set by the researcher. In light of foregoing, education process at meso-level, i.e. P3TK Division during Covid-19 pandemic has been implemented in sound and effective manner by the staff, and able to encourage harmonized sense in delivering services to education staff in the field.

\section{Discussion}

The result of this study is, first, in terms of quality assurance of transformational leadership, this study reveals that there are important aspects of finding evidence of the validity of scores resulting from quality assurance of leadership values measurement includes aspects:
1) Logical / Theoretical Analysis; 2) Latent Process Studies; 3) Practical Constraints; 4) Item Design Principles; 5) Domain Structure; 6) Test Specifications; 7) Psychometric Properties; 8) Scoring Models; 9) Utility; 10) Other Measures; and 11) Impact [16].

Quality Assurance is a pro-active process that emphasizes planning, documenting, and determining quality guidelines at the beginning of the project to understand the requirements and expected quality standards. After all the requirements and desired quality standards have been identified, it is necessary to develop a plan to meet the requirements and desired quality standards. There are three techniques or tools used to ensure the quality of a product, namely Quality Audit, Process Analysis, Quality Management, and Tool of controls [10].

It means that the implementation of the quality assurance education process at the mess (district/city) level occurs in the value of leadership towards educational followers/ staples, which will lead to excellent service for the implementation of education at the micro/educational unit level.

Second, Regarding the implementation of transformational leadership, this depends on the transformational leadership style, seen in the process by which leaders and followers increase morality and motivation to a higher level.

This kind of leadership style will be able to bring awareness of followers (followers) by bringing up productive ideas, synergistic relationships, responsibility, educational care, and shared ideals [9]. Thus, the importance of the leadership aspect in the educational process will bring followers or in the mess dimension, that staff is in high welfare, creating organizational harmonization.

\section{CONCLUSION}

Quality assurance of transformational leadership to the followers during Covid-19 pandemic in education world is crucial to maximize the performance of followers and to maintain the overall education system remain harmonious in service delivery in pursuit of the specified objectives of Indonesia National Education. Covid-19 has impacted the entire aspects of education process system, which one of them is in education resources aspect or component. The latter needs intensive development from education stakeholders especially from prosperity wise. When education resources feel prosperous and their performance is harmonized through transformational leadership then stable positive performance will be created. Education process at meso-level, in this case at P3TK Division during Covid-19 pandemic, has run well and effectively and at staff level, able to encourage harmonized sense in delivering services to education staff that operate in the field. 


\section{REFERENCES}

[1] D. Meirawan, "Penjaminan Mutu Satuan Pendidikan Sebagai Upaya Pengendalian Mutu Pendidikan Secara Nasional dalam Otonomi Pendidikan," Educationist, vol. IV, no. 2, pp. 126-137, 2010.

[2] A. Nursyifa, "Kepemimpinan Kepala Sekolah dalam Menghadapi Era Revolusi Industri 4.0: Perspektif Sosiologi Pendidikan,” J. Pendidik. Kewarganegaraan, vol. 6, no. 2, p. 143, 2019.

[3] I. S. Maris, A. Komariah, and A. Bakar, "Kepemimpinan Transformasional Kepala Sekolah, Kinerja Guru Dan Mutu Sekolah,” J. Adm. Pendidik., vol. 23, no. 2, 2016.

[4] W. Strielkowski and J. Wang, "An Introduction : COVID-19 Pandemic and Academic Leadership,” vol. 441, pp. 1-4, 2020.

[5] U. S. Saud, Bunga Rampai Administrasi Pendidikan Teori dan Praktik, 2nd editio. Bandung: Alfabeta, 2019.

[6] K. Amalia, A. Komariah, S. Sumarto, K. H. Asri, and U. P. Indonesia, "Leadership in Education:," vol. 400, no. Icream 2019, pp. 134-137, 2020.

[7] M. Syah, Psikologi Pendidikan dengan Pendekatan Baru, 11th editi. Bandung: PT.Remaja Rosdakarya, 2005

[8] G. D. Doherty, Developing Quality Systems in Education. London and New York: Routledge, 2005.

[9] A. Bukhari, "Kepemimpinan Transformasional Pendidikan Berbasis Total Quality Manajement (TQM),' J. Din. Ilmu, vol. 12, no. 2, pp. 114, 2012.
[10] B. Kho, "Pengertian Quality Control dan Quality Assurance (QC dan QA)," Ilmu Manaj. Ind., 2017. [Online]. Available: https://ilmumanajemenindustri.com/perbedaan-pengertian-qualitycontrol-qc-quality-assurance-qa/.

[11] A. M. Mirfani, "Quality Assurance of Classroom Management for Spiritual Values-oriented Learning,” vol. 258, no. Icream 2018, pp. 167 171, 2019.

[12] M. S. J, Validity of psychological assessment: Validation of inferences from persons' responses and performances as scientific inquiry into score meaning. American Psychologist. Amerika: American Psychologist, 1995.

[13] M. S. J, Validity and Washback in Language Testing. Research Report No.96-17 Princeton, NJ: Educational Testing Service. NJ: Educational Testing Service, 1996.

[14] M. S.J, Consequences of Test Interpretation and Use: The Fusion of Validity and Values in Psychological Assessment. Research Report No. 98-48. Princeton,. NJ: Educational Testing Service., 1998.

[15] K. Direktorat Penjaminan Mutu, Dirjen Belmawa, "Pedoman Sistem Penjaminan Mutu Internal - Pend. Akademik, Vokasi, Profesi dan PJJ,' pp. 1-193, 2018.

[16] Embretson, Construct Validity: A Universal Validity System or Just Another Test Evaluation Procedure? Educational Researcher. 2007.

[17] D. E. Kusumaningrum and E. M. Budiarti, "Implementation of Transformational Leadership Style in Improving the Quality of Institutions," vol. 381, no. CoEMA, pp. 207-211, 2019. 